\title{
Prevalence of Shielding in Diagnostic X-ray Centers in the Islamic Republic of Iran: A Systematic Review
}

\author{
Mohammad Chavideh ${ }^{1}$, Seyed Reza Khorshidi ${ }^{2}$, Alireza Bagzahedi Baghmalek ${ }^{2}$, Raheleh Hassanvand \\ Amoozadeh $^{2}$, Razieh Naserifar ${ }^{2}$, Araf Alekasir ${ }^{2}$, Yousef Bolandnazar ${ }^{2}$, Mohammad Najafi $^{2} \&$ Ali Arianezhad ${ }^{1}$ \\ ${ }^{1}$ Student Research Committee, Dezful University of Medical Sciences, Dezful, Iran \\ ${ }^{2}$ Department of Medical Engineering, School of Technical and Engineering, Dezful Branch, Islamic Azad \\ University, Dezful, Iran \\ Correspondence: Ali Arianezhad, Student Research Committee, Dezful University of Medical Sciences, Dezful, \\ 6461665145, Iran. Tel: 98-9031801896. E-mail: ali.arianezhad76@gmail.com
}

Received: December 7, 2018; Accepted: December 21, 2018; Published: December 27, 2018

The research is financed by Student Research Committee of Dezful University of Medical Sciences (Approval No. IR.DUMS.REC.1398.005).

\begin{abstract}
Shielding has been recommended as an effective tool against radiation exposure. Several studies have published on the availability and use of shielding tools in diagnostic X-ray centers across the country and contradictory results been reported. Therefore, the aim of this systematic review was to find out the status of radiation protection in term of availability and use of shielding tools in diagnostic X-ray centers in Iran. An extensive literature search was conducted in the PubMed/Medline, Embase, ISI, Cochrane Library, SID, Magiran, IranMedex, Irandoc and Google-Scholar search engine. We also manually searched the reference lists of the relevant studies. Two authors independently assessed the eligibility of all studies and extracted data. Thirty-seven studies published from 1998 to 2019 were included in this systematic review. In all, 1089 diagnostic X-ray centers, 4439 radiographs and performance of 1472 radiographers were covered in these studies. The availability of lead apron, gonad shield and thyroid collar were ranged from 7 to $95.5 \%, 26.6$ to $94 \%$ and 7 to $94 \%$, respectively. Moreover, their usage was ranged from 0 to $85.5 \%, 0$ to $35 \%$ and 0 to $38.4 \%$, respectively. In addition, lens shield was discussed in one study with availability of $0 \%$. During 1998 to 2019 , the status of shielding had not improved across the country. Therefore adherence to the safety guideline as far as possible is required to protection patients from undue exposure to radiation.
\end{abstract}

Keywords: prevalence, shielding, diagnostic X-ray, radiation exposure, Iran

\section{Introduction}

In the recent years, there has been a remarkable increase in the number of patients undergoing diagnostic X-ray procedures [1-5]. It is estimated that more than 471 million diagnostic X-ray procedures were performed in the United States in 2008, up from 267 million in 1998 [3]. While ionizing radiations has revolutionized medical diagnosis, their use is associated with adverse health effects, especially increasing the life time risk for developing cancer [1, 2, 6-12]. Therefore, it is necessary to reduce radiation exposure of patients as low as possible [13-16].

Shielding is one of the fundamental methods used to reduce radiation exposure in patients undergoing diagnostic X-ray procedures [2, 17-21]. Several radiosensitive tissues such as the lens of the eye, thyroid gland, breast and gonad may benefit from shielding [22]. Traditionally, lead and bismuth-based radiation shields have been used for radiation dose reduction during X-ray procedures [22-24]. Lead shields intended to reduce radiation exposure from tissues that located outside from the radiation field and therefore, are not under diagnostic evaluation (e.g. gonad shielding during pediatric chest radiography or breast shielding during computed tomography (CT) of the head) [25]. In contrast, bismuth shields reduce radiation exposure from tissues that located within the radiation field and should be appear in the resultant image (e.g. gonad shielding during pelvic radiography or breast shielding during thoracic CT) (25). Shielding provides substantial protection against radiation exposure. Evidence showed that 1$\mathrm{mm}$ lead can reduce radiation exposure by $99.4 \%$ [26]. Similarly, bismuth shields could reduce radiation exposure by 17 to $62 \%$, based on anatomical region and X-ray tube setup [18, 27]. Although the effectiveness of shielding 
has been documented for some X-ray examinations, evidence showed that shielding tools are not available in some $\mathrm{X}$-ray centers and if so, their use is frequently ignored $[17,28]$. Several studies have focused on the availability and use of shielding tools in diagnostic X-ray centers across the country and contradictory results been reported. Moreover, their availability and usage differ from city to city and center to center. Therefore, the aim of this systematic review was to find out the status of radiation protection in term of availability and use of shielding tools in diagnostic X-ray centers in Iran. This study would be benefit to address the existence status, current problems and plans for the future.

\section{Method}

This study was performed according to the preferred reporting items for systematic review and meta-analysis (PRISMA) statements [29]. The ethic committee of Dezful University of Medical Sciences has approved the concept and context of the study.

\subsection{Literature Search}

The electronic search was performed in the national and international databases of PubMed/Medline, Embase, ISI web of knowledge, Cochrane Library, SID, Magiran, IranMedex, Irandoc and Google-Scholar search engine. The following key worlds and their Persian equivalents (for national databases) were searched with assistance an experienced librarian: "shielding, gonad shield, thyroid collar, lead apron, lens shield, bismuth shield, X-ray, radiation protection, patient, radiography, computed tomography, CT, mammography, dental radiography and Iran"'. Moreover, the reference list of the potentially relevant studies, reviews and book chapters were screened to identify additional relevant studies. Posters presented at two Iranian radiology conferences [30,31] were screened to contribute "gray literatures" as well. Finally, we contact with corresponding author of the retrieved studies that met our inclusion criteria to nominate missing studies.

\subsection{Inclusion and Exclusion Criteria}

We included studies that reported data on the availability, use or both the availability and use of shielding tools (lens shield, thyroid shield, breast shield, gonad shield, lead gloves and lead aprons) in diagnostic X-ray centers (conventional radiography, CT, mammography and dental radiography) in Iran. Both English and Persian language studies were included without any time limitation. Other non-relevant studies that did not met our inclusion criteria were excluded from the study.

\subsection{Study Selection}

First, the title and abstract of the study form the original search were independently reviewed by two authors (M.C and A.A). If paper identified as eligible by at least 1 author, the full text was retrieved and evaluated. The reference lists of the retrieved studies were imported to Endnote software (Thompson Reuters, CA) to remove duplicate studies. The inclusion criteria were independently applied by two authors (Y.B and M.N) and disagreements were resolved by discussion. If agreement was not reached, the disputes were resolved by the third author (R.N).

\subsection{Data Extraction}

The following data were extracted by two authors (Y.B and M.N) in consensus: (a) authors name, (b) type of publication, (c) city/province where the study was performed, (d) year of publication, (e) sample size, (f) availability and use of shielding tools in X-ray centers and $(\mathrm{g})$ any additional relevant information.

\section{Results}

\subsection{Characteristics of Identified Studies}

The search flowchart is shown in figure 1. In all, 37 studies comprising 32 research papers and 5 gray literatures ( 3 conference paper and 2 thesis) published from 1998 to 2019 were included in this systematic review. Studies were performed in conventional radiography $(n=24)$, dental radiography $(n=11)$, mammography $(n=1)$ and CT $(\mathrm{n}=1)$ centers. One study was covered both the conventional radiography and dental radiography centers, as well. Studies were originated from 11 different cities, 6 different provinces and 2 studies across the country. In all, 1089 diagnostic X-ray centers, 4439 radiographs and performance of 1472 radiographers were covered in these studies. In term of methodology, 16 studies were used of questionnaire for data collection and 13 studies were based on direct observation. Moreover, in six studies, the archived radiographs were retrospectively assessed for investigating the evidence of shielding.

\subsection{Prevalence of Shielding}

The lead and bismuth-based radiation shields were discussed in 34 and 3 out of 37 studies, respectively. The availability of lead apron, gonad shield and thyroid collar were ranged from 7 to $95.5 \%, 26.6$ to $94 \%$ and 7 to $94 \%$, 
respectively. Moreover, their usage was ranged from 0 to $85.5 \%, 0$ to $35 \%$ and 0 to $38.4 \%$, respectively. In addition, lens shield was discussed in one study with availability of $0 \%$. Eight studies provided data regarding total availability or use of shielding tools without clarification the type of shielding tools. Table 1 shows the details of the studies.

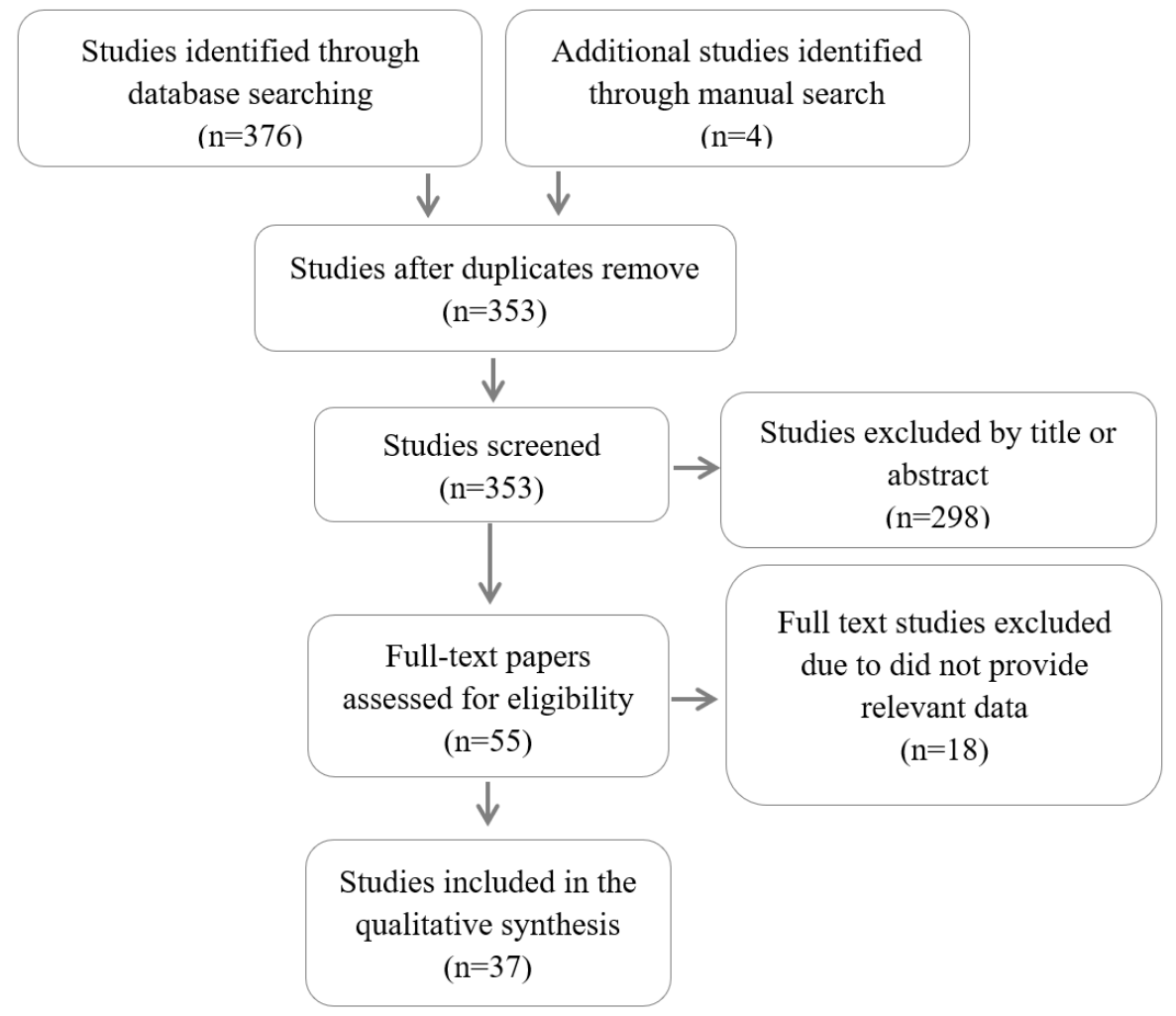

Figure 1. Study flowchart

Table 1. Characteristic of the studies reported the prevalence of shielding in diagnostic X-ray centers in Iran.

\begin{tabular}{|c|c|c|c|c|c|}
\hline $\begin{array}{l}\text { Study location } \\
\text { (Published } \\
\text { Year) }\end{array}$ & $\begin{array}{l}\text { X-ray } \\
\text { center }\end{array}$ & Methodology & $\begin{array}{l}\text { Sample } \\
\text { size }\end{array}$ & Main results & Ref \\
\hline $\begin{array}{l}\text { Dezful } \\
(2019)\end{array}$ & $\mathrm{CR}$ & Retrospective & $498^{\mathrm{a}}$ & $\begin{array}{l}\text { Of } 498 \text { evaluated chest and abdomen radiographs, only } 0.4 \% \\
\text { had evidences of shielding. }\end{array}$ & {$[\underline{61}]$} \\
\hline $\begin{array}{l}\text { Ahvaz } \\
(2018)\end{array}$ & $\mathrm{CR}$ & Retrospective & $380^{a}$ & $\begin{array}{l}\text { Bismuth shield was present in } 154 \text { out of } 198 \text { radiographs of } \\
\text { the boys and } 170 \text { out of } 182 \text { radiographs of the girls. }\end{array}$ & [24] \\
\hline $\begin{array}{l}\text { Ahvaz } \\
(2017)\end{array}$ & $\mathrm{CR}$ & Retrospective & $238^{\mathrm{a}}$ & $\begin{array}{l}\text { Lead and bismuth-based gonadal shields were presented in } 47 \\
(19.75 \%) \text { and } 61(25.7 \%) \text { out of } 238 \text { pelvic x-rays of the boy } \\
\text { patients, respectively. } 34 \% \text { of lead shields and } 80 \% \text { of bismuth } \\
\text { shields were protected the gonads without compromising } \\
\text { image quality. }\end{array}$ & [18] \\
\hline $\begin{array}{l}\text { Kermanshah } \\
(2017)\end{array}$ & $\mathrm{CR}$ & Questionnaire & $38^{\mathrm{b}}$ & $\begin{array}{l}\text { Shielding tools was never applied for patients. The frequency } \\
\text { use of shielding tools for the radiographers and non- } \\
\text { radiographer personnel were } 100 \% \text { and } 28.9 \% \text {, respectively. }\end{array}$ & [므] \\
\hline $\begin{array}{l}\text { Ahvaz } \\
(2017)\end{array}$ & $\mathrm{CR}$ & Observational & $25^{\mathrm{c}}$ & $\begin{array}{l}\text { Lead apron, gonad shield and thyroid collar was available in } \\
96 \%, 94 \% \text { and } 94 \% \text { of X-ray rooms, respectively. } \\
28 \% \text { of radiographers were applied shielding tools for the } \\
\text { pregnant mothers and children. }\end{array}$ & [42] \\
\hline $\begin{array}{l}\text { Ahvaz } \\
(2016)\end{array}$ & $\mathrm{CR}$ & Retrospective & $348^{\mathrm{a}}$ & $76.5 \%$ of radiographers never used any shielding tools & [19] \\
\hline
\end{tabular}




\begin{tabular}{|c|c|c|c|c|c|}
\hline $\begin{array}{l}\text { Ahvaz } \\
(2016)\end{array}$ & $\mathrm{CR}$ & Retrospective & $1230^{\text {a }}$ & Gonad shield was present in $6.6 \%$ of radiographs evaluated. & {$[\underline{37}$} \\
\hline $\begin{array}{l}\text { Ahvaz } \\
(2016)\end{array}$ & $\mathrm{CR}$ & Retrospective & $1745^{\text {a }}$ & $\begin{array}{l}\text { Gonad shield was present in } 2.9 \% \text { of the girls' radiographs and } \\
7.6 \% \text { of the boys' radiographs. }\end{array}$ & {$[\underline{38}]$} \\
\hline $\begin{array}{l}\text { Ahvaz } \\
(2015)\end{array}$ & $\mathrm{CR}$ & Observational & $30^{\mathrm{c}}$ & $\begin{array}{l}\text { More than } 97 \% \text { of the hospitals evaluated benefited from } \\
\text { adequate shielding tools. } \\
\text { The prevalence use of shielding tools in hospitals where } \\
\text { shielding was available, varied from } 5.2 \% \text { to } 14 \% \text {. }\end{array}$ & [17] \\
\hline $\begin{array}{l}\text { Ahvaz } \\
(2015)\end{array}$ & $\mathrm{CR}$ & Observational & $5^{\mathrm{c}}$ & $\begin{array}{l}\text { In } 64.3 \% \text { of X-ray rooms, at least one flat contact gonad shield } \\
\text { with large size was available. Only large size of gonad shields } \\
\text { was available. } \\
\text { The prevalence use of gonad shielding was less than } 0.2 \% \text {. }\end{array}$ & {$[\underline{28}]$} \\
\hline $\begin{array}{l}\text { Khuzestan } \\
(2015)\end{array}$ & $\mathrm{CR}$ & Questionnaire & $185^{\mathrm{b}}$ & $\begin{array}{l}\text { During portable radiography, } 85.5 \% \text { of the radiographers were } \\
\text { used of lead apron. } \\
\text { In stationary radiography, } 31.35 \% \text { of the radiographers were } \\
\text { used of gonad shield. }\end{array}$ & [무] \\
\hline $\begin{array}{l}\text { Kermanshah } \\
(2015)\end{array}$ & $\mathrm{CR}$ & Observational & $8^{c}$ & $\begin{array}{l}\text { Lead apron, gonad shield and thyroid collar were available in } \\
87.5 \%, 75 \% \text { and } 75 \% \text { of X-ray rooms, respectively. }\end{array}$ & {$[\underline{43}]$} \\
\hline $\begin{array}{l}\text { Ahvaz } \\
(2013)\end{array}$ & $\mathrm{CR}$ & Observational & $5^{c}$ & $\begin{array}{l}\text { Thyroid collar and gonad shield was never applied for the } \\
\text { patients. }\end{array}$ & {$[\underline{34}]$} \\
\hline $\begin{array}{l}\text { Yazd } \\
(2013)\end{array}$ & $\mathrm{CR}$ & Questionnaire & $17^{\mathrm{b}}$ & The prevalence use of gonad shield was $43.59 \%$. & {$[\underline{36}]$} \\
\hline $\begin{array}{l}\text { Zahedan } \\
(2012)\end{array}$ & $\mathrm{CR}$ & Observational & $29^{\mathrm{c}}$ & $\begin{array}{l}\text { The availability of lead apron, thyroid collar and gonad shield } \\
\text { were } 95.5 \%, 79 \% \text { and } 62 \% \text {, respectively. } \\
34 / 48 \% \text { of radiographers were used lead apron only for } \\
\text { pregnant patients and children. }\end{array}$ & {$[\underline{44}]$} \\
\hline $\begin{array}{l}\text { Hamadan } \\
(2011)\end{array}$ & $\mathrm{CR}$ & Questionnaire & $71^{\mathrm{b}}$ & The prevalence use of shielding tools was $78.9 \%$. & {$[\underline{63}]$} \\
\hline $\begin{array}{l}\text { Kerman } \\
(2009)\end{array}$ & $\mathrm{CR}$ & Observational & - & $\begin{array}{l}\text { The availability and prevalence use of shielding tools was } 90 \% \\
\text { and } 1 \% \text {, respectively. }\end{array}$ & [64] \\
\hline $\begin{array}{l}\text { Sanandaj } \\
(2007)\end{array}$ & $\mathrm{CR}$ & Questionnaire & $4^{\mathrm{b}}$ & Gonad shield was available in $37 \%$ of X-ray centers. & {$[\underline{41}]$} \\
\hline $\begin{array}{l}\text { Mazandaran } \\
(2007)\end{array}$ & $\mathrm{CR}$ & Observational & $20^{\mathrm{c}}$ & $\begin{array}{l}\text { The prevalence use of thyroid collar and gonad shield for } \\
\text { patients was } 0.3 \% \text {. }\end{array}$ & {$[\underline{45}]$} \\
\hline $\begin{array}{l}\text { Shiraz } \\
(2006)\end{array}$ & $\mathrm{CR}$ & Questionnaire & $51^{\mathrm{b}}$ & $\begin{array}{l}\text { The availability and prevalence use of shielding tools was } 80 \% \\
\text { and } 91.8 \% \text {, respectively. }\end{array}$ & {$[\underline{65}]$} \\
\hline $\begin{array}{l}\text { Mazandaran } \\
(2005)\end{array}$ & $\mathrm{CR}$ & Questionnaire & $15^{\mathrm{b}}$ & The availability of shielding tools was $26 \%$. & {$[\underline{66}]$} \\
\hline $\begin{array}{l}\text { Hamadan } \\
(2004)\end{array}$ & $\begin{array}{l}\mathrm{CR} \text { and } \\
\mathrm{DR}\end{array}$ & Questionnaire & $5^{\mathrm{b}}$ & $\begin{array}{l}\text { The prevalence use of lead apron was } 58.3 \% \text { and } 4.5 \% \text { in } \\
\text { conventional radiology and dental radiography, respectively. }\end{array}$ & {$[\underline{60}]$} \\
\hline $\begin{array}{l}\text { Kerman } \\
(2003)\end{array}$ & $\mathrm{CR}$ & Observational & $39^{\mathrm{c}}$ & Shielding was never regarded in clinical practice. & {$[\underline{35}]$} \\
\hline $\begin{array}{l}\text { Azerbaijan } \\
(2001)\end{array}$ & $\mathrm{CR}$ & Observational & $81^{\mathrm{c}}$ & $\begin{array}{l}\text { Of } 81 \text { hospitals evaluated, the frequency use of lead apron and } \\
\text { lens shield for patients were } 25.5 \% \text { and } 2.8 \% \text {, respectively. }\end{array}$ & {$[\underline{48}]$} \\
\hline $\begin{array}{l}\text { Boshehr } \\
(2001)\end{array}$ & $\mathrm{CR}$ & Observational & $30^{\mathrm{c}}$ & $\begin{array}{l}\text { Of } 30 \mathrm{X} \text {-ray rooms evaluated, lead apron and gonad shield } \\
\text { were not available in } 5 \text { and } 22 \mathrm{X} \text {-ray rooms, respectively. Lead } \\
\text { apron was never applied for the patients as well. }\end{array}$ & {$[\underline{46}]$} \\
\hline $\begin{array}{l}\text { Mashhad } \\
(2018)\end{array}$ & DR & Questionnaire & $232^{\mathrm{c}}$ & $\begin{array}{l}\text { Lead apron and thyroid gland were not applied for the patients } \\
\text { in } 54.7 \% \text { and } 61.6 \% \text { of x-ray centers. }\end{array}$ & {$[57]$} \\
\hline $\begin{array}{l}\text { Kerman } \\
(2014)\end{array}$ & DR & Questionnaire & $106^{\mathrm{c}}$ & $\begin{array}{l}\text { Lead apron and thyroid gland were available in } 12 . .3 \% \text { and } \\
10.4 \% \text { of X-ray centers, respectively. } \\
\text { Only } 5.7 \% \text { of X-ray centers were used of lead apron for the } \\
\text { patients. }\end{array}$ & {$[\underline{56}]$} \\
\hline $\begin{array}{l}\text { Iran } \\
(2012)\end{array}$ & DR & Questionnaire & $700^{\mathrm{b}}$ & $\begin{array}{l}1 \% \text { of practitioners were used of thyroid collar and lead aprons } \\
\text { regularly and } 34 \% \text { occasionally. }\end{array}$ & {$[\underline{58}]$} \\
\hline
\end{tabular}




\begin{tabular}{|c|c|c|c|c|c|}
\hline $\begin{array}{l}\text { Rasht } \\
(2011)\end{array}$ & $\mathrm{DR}$ & Questionnaire & $110^{\mathrm{b}}$ & $\begin{array}{l}\text { The prevalence use of lead apron and thyroid collar was less } \\
\text { than } 1 \% \text {. }\end{array}$ & {$[\underline{59}]$} \\
\hline $\begin{array}{l}\text { Isfahan } \\
(2011)\end{array}$ & $\mathrm{DR}$ & Questionnaire & $184^{\mathrm{b}}$ & $\begin{array}{l}\text { The prevalence use of lead apron and thyroid collar was } 10 \% \\
\text { and } 4.5 \% \text {, respectively. }\end{array}$ & {$[\underline{55}]$} \\
\hline $\begin{array}{l}\text { Iran } \\
(2009)\end{array}$ & $\mathrm{DR}$ & Questionnaire & $18^{\mathrm{b}}$ & $\begin{array}{l}\text { The availability and prevalence use of thyroid collar and lead } \\
\text { apron were } 16.7 \% 22.2 \% \text {, respectively. }\end{array}$ & {$[\underline{53}]$} \\
\hline $\begin{array}{l}\text { Tehran } \\
(2006)\end{array}$ & DR & - & - & The prevalence use of lead apron was $21.9 \%$. & {$[\underline{54}]$} \\
\hline $\begin{array}{l}\text { Tehran } \\
(2004)\end{array}$ & DR & Observational & $200^{\mathrm{c}}$ & $\begin{array}{l}\text { In } 93 \% \text { of } x \text {-ray centers, there was no lead apron and thyroid } \\
\text { collar. In the remaining } 7 \% \text {, their use was } 5 \% \text { and } 2 \% \text {, } \\
\text { respectively. }\end{array}$ & {$[\underline{52}]$} \\
\hline $\begin{array}{l}\text { Yazd } \\
(2004)\end{array}$ & $\mathrm{DR}$ & Questionnaire & $40^{\mathrm{b}}$ & Lead apron and thyroid collar was never applied for patients. & {$[\underline{51]}$} \\
\hline $\begin{array}{l}\text { Isfahan } \\
(1998)\end{array}$ & $\mathrm{DR}$ & - & $274^{c}$ & The prevalence use of lead apron was $16 \%$. & {$[\underline{50}]$} \\
\hline $\begin{array}{l}\text { Shiraz } \\
(2012)\end{array}$ & MG & Questionnaire & $5^{\mathrm{b}}$ & $\begin{array}{l}\text { In } 80 \% \text { of the mammography divisions, there was no special } \\
\text { radiation protection shield used for the patients }\end{array}$ & {$[\underline{67}$} \\
\hline $\begin{array}{l}\text { Ahvaz } \\
(2015)\end{array}$ & $\mathrm{CT}$ & Observational & $5^{\mathrm{c}}$ & $\begin{array}{l}\text { No bismuth shield was available. The availability of lead- } \\
\text { based gonadal, thyroid collar, lens and breast shields was } 70 \text {, } \\
62,0 \text { and } 100 \% \text {, respectively. Their prevalence of use was } 3.6 \text {, } \\
0,0 \text { and } 2.6 \% \text {, as well. }\end{array}$ & {$[25]$} \\
\hline
\end{tabular}

\section{Discussion}

To our knowledge, our study is the first systematic review on the prevalence of shielding in diagnostic X-ray centers in Iran. In this study, the availability and use of various shielding tools such as lead apron, gonad shield, thyroid collar and lens shield, originated from 1089 diagnostic X-ray centers, 4439 radiographs and performance of 1472 radiographers is covered.

The germ cells within the gonads are highly sensitive to radiation and therefore, it is necessary to reduce their received dose as low as possible $[18,32,33]$. Traditionally, when the gonads located at or closer $(5-\mathrm{cm})$ to the primary radiation field, gonad shielding should be perform, unless its presence compromise diagnostic image quality [32]. According to literatures, gonad shielding was discussed in 14 studies with availability and prevalence use of 26.6 to $94 \%$ and 0 to $35 \%$, respectively. Two studies reported that gonad shielding was never applied for patients $[34,35]$. Similarly, one another study reported even if gonad shields were available in $64.3 \%$ of X-ray rooms, their use was ignored [28]. In opposite, one questionnaire-based study showed that $35 \%$ of radiographers were used of gonad shield for the patients [36]. Two retrospective studies were focused on the use of gonad shield during pelvic radiography and reported the prevalence use of no more than $7.6 \%[37,38]$. Moreover, two studies were assessed frequency use of bismuth-based gonadal shields for pediatric pelvic radiography [18, 24]. The first study reported the prevalence use of $93.4 \%$ for the girls and $77.7 \%$ for the boys, without compromising image quality [24]. In the second study, the frequency use of $25.7 \%$ for the boys with satisfactory protection rate of $80 \%$ was reported [18]. The difficulty associated with accurate positioning of the shield may be the main source for omission of gonad shielding in procedures that the gonads included in the primary radiation field [39]. This drawback is more problematic for female patients than males due to complex anatomical position of the ovaries [40]. However, data from 9 studies are ambiguous in term of inclusion or exclusion of the gonads in the primary radiation field and patients' sex [34-36, 41-46].

Lead apron is an effective tool against radiation exposure. It can cover 75 to $80 \%$ of the bone marrow [32] and reduce the scatter radiation by approximately $98 \%$ [47]. Lead apron was discussed in as vastly as 18 studies in the literatures with distribution of 7 studies in conventional radiography [17, 42-44, 46, 48, 49], 10 studies in dental radiography [50-59] and 1 study in both conventional and dental radiography [60]. The availability and prevalence use of lead apron was 87.5 to $97 \%$ and 25.5 to $85.5 \%$ in conventional radiography and 7 to $44.3 \%$ and 0 to $22.2 \%$ 
in dental radiography, respectively. However, some radiographers believe that frequent use of lead apron would result in back pain and ergonomic disease.

During head, neck and dental radiography and neck and thoracic CT in particular, thyroid gland receives unavoidable radiation exposure. Therefore, thyroid shielding is of great value to reduce thyroid gland dose, when its presence does not compromise diagnostic image quality [22]. The availability and use of thyroid shield was varied between studies and X-ray centers. Its availability and usage was ranged from 75 to $94 \%$ and 0 to $0.3 \%$ in conventional radiography and 10.4 to $16.7 \%$ and 0 to $38.4 \%$ in dental radiography, respectively. Moreover, one study was identified in the literatures discussed thyroid shielding in CT centers [25]. However, results are concerning due to thyroid shielding was never applied for the patients.

The lens of the eye is highly radiosensitive, especially in children [23]. Bismuth-eye-shield has shown to be effective at reducing radiation dose during $\mathrm{CT}$ exams [22,23]. The radiation dose reduction up to $50 \%$ with no effect on image quality has been reported during head CT [23]. However, eye shielding was not covered as many as other radiosensitive organs. Only one study was identified in the literatures discussed lens shielding during CT exams with availability of and usage of $0 \%$ [25].

CT exposes patients to much more radiation than other diagnostic imaging modalities. It is estimated that CT constitute $67 \%$ of the effective dose from all medical X-ray examinations [1]. However, it was not covered as many as other imaging modalities. Therefore, a better evaluation of shielding in CT centers is required to occur in the future studies. There was a gap between data from observational and retrospective studies with questionnaire studies. The availability and prevalence use of shielding tools was more common in questionnaire than in observational and retrospective studies. It is assumed that data from observational and retrospective studies may be more reliable than studies who their authors used questionnaire to data collection. Therefore, more care is required in applying the findings of these studies. Even if various radiation protection training courses has been annually performed in the country, the statues of shielding does not improved across the country over two past decades. This fact may be due to ineffectiveness of these training courses. Karami et al. believed that most of the radiographers do not follow the professional ethical issues [8].

Among the limitations of the current study, the following could be mentioned: 1) different methodology, 2) type of X-ray examinations, patients' age and sex were not reported in several studies.

In conclusion it can be said that during 1998 to 2019, the status of shielding had not improved across the country. Therefore adherence to safety guidelines as far as possible is required to protection patients from undue exposure to radiation.

\section{Acknowledgments}

Special thanks from the student research committee of Dezful University of Medical Sciences for the financial support (Approval No. IR.DUMS.REC.1398.005).

\section{References}

[1] Karami, V., \& Gholami, M. (2018). Addressing as Low as Reasonably Achievable (ALARA) in Pediatric Computed Tomography (CT) Procedures. Journal of Research in Medical and Dental Science, 6(5),104-14.

[2] Karami, V., \& Zabihzadeh, M. (2016). Review on radiation protection in diagnostic radiology. Tehran University Medical Journal TUMS Publications, 74(7), 457-66.

[3] Rothenberg, B. M., \& Korn, A. (2005). The opportunities and challenges posed by the rapid growth of diagnostic imaging. Journal of the American College of Radiology, 2(5), 407-410. https://doi.org/10.1016/j.jacr.2005.02.012

[4] Zabihzadeh, M., \& Karami, V. (2016). The challenge of unnecessary radiological procedures. Hong Kong Journal of Radiology, 19(3), 23-4. https://doi.org/10.12809/hkjr1615363

[5] Karami, V., \& Zabihzadeh, M. (2017). Beam collimation during lumbar spine radiography: A retrospective study. Journal of Biomedical Physics \& Engineering, 7(2), 101-106.

[6]Shrieve, D. C., \& Loeffler, J. S. (2010). Human radiation injury: Lippincott Williams \& Wilkins.

[7] Karami, V. (2018). Fetography: The global outdated procedure, the national prevalent procedure: letters to the editor. Tehran University Medical Journal TUMS Publications, 76(2):153.

[8] Karami, V., \& Zabihzadeh, M. (2016). Radiation protection in diagnostic X-ray imaging departments in Iran: a systematic review of published articles. Journal of Mazandaran University of Medical Sciences, 26(135), 175-88. 
[9] Karami, V., \& Zabihzadeh, M., Danyaei, A., \& Shams, N. (2016). Efficacy of increasing focus to film distance (FFD) for patient's dose and image quality in pediatric chest radiography. International Journal of Pediatrics, 4(9), 3421-9. https://doi.org/10.22038/IJP.2016.7319

[10] Karami, V., Zabihzadeh, M., \& Keshtkar, M. (2017). Evaluation of the Entrance Surface Dose (ESD) and Radiation Dose to the Radiosensitive Organs in Pediatric Pelvic Radiography. International Journal of Pediatrics, 5(6), 5013-5022. https://doi.org/10.22038/IJP.2017.22364.1873

[11] Zabihzadeh, M., \& Karami, V. (2016). Letter to Editor: Poor collimation in digital radiology: A growing concern. Internet Journal of Medical Update-EJOURNAL, 11(2), 29-30. https://doi.org/10.4314/ijmu.v11i2.7

[12] Karami, V., Zabihzadeh, M., Shams, N., \& Gholami, M. (2017). Evaluation of the anode heel effect on the testes dose during pelvic radiography. Tehran University Medical Journal TUMS Publications, 75(2), 113-9.

[13] Karami, V., Zabihzadeh, M., Shams, N., \& Malehi, A. S. (2017). Gonad Shielding during Pelvic Radiography: A Systematic Review and Meta-analysis. Archives of Iranian Medicine, 20(2), 113-23. https://doi.org/0172002/AIM.0011

[14] Zabihzadeh M, Karami V. Current status of the fetography: Preventing of the future radiation induced cancer. Iranian Journal of Cancer Prevention, 10(1), e5209. https://doi.org/10.17795/ijcp-5209

[15] Karami, V., Zabihzadeh, M., Shams, N., \& Gilavand, A. (2017). Optimization of Radiological Protection in Pediatric Patients Undergoing Common Conventional Radiological Procedures: Effectiveness of Increasing the Film to Focus Distance (FFD). International Journal of Pediatrics, 5(4), 4771-4782. https://doi.org/10.22038/ijp.2017.22010.1841

[16] Hassanpour, N., Panahi, F., Naserpour, F., Karami, V., Asl, J. F., \& Gholami, M. (2018). A Study on Radiation Dose Received by Patients during Extracorporeal Shock Wave Lithotripsy. Archives of Iranian Medicine (AIM), 21(12), 585-588.

[17] Behroozi, H., Tahmasebi, M., Mohebifar, B. (2018). Evaluation of the Prevalence of Shielding in Patients Undergoing Conventional Radiological Procedures (1 Work Shift-1 X-ray Room). Journal of Patient Safety, 14(3), 133-137. https://doi.org/10.1097/PTS.0000000000000180

[18] Karami, V., Zabihzadeh, M., Shams, N., Gholami, M. (2017). Radioprotection to the Gonads in Pediatric Pelvic Radiography: Effectiveness of Developed Bismuth Shield. Int. J. Pediatr, 5(6), 5153-5166. https://doi.org/10.22038/ijp.2017.23116.1939

[19] Karami, V., Zabihzadeh, M., Gilavand, A., \& Shams, N. (2016). Survey of the use of X-ray beam collimator and shielding tools during infant chest radiography. International Journal of Pediatrics, 4(4), 1637-1642. https://doi.org/10.22038/ijp.2016.6708

[20] Karami, V., Zabihzadeh, M., Gholami, M., Shams, N. F., \& Nezhad. Z. (2016). Dose reduction to the thyroid gland in pediatric chest radiography. Int. J. Pediatr, 4(7), 2183-91. https://doi.org/10.22038/ijp.2016.7081

[21] Karami, V. (2015). Report a concern: Letter to the editor. Tehran Univ. Med. J., 73(7), 544.

[22] Morford, K., \& Watts, L. K. (2012) .Bismuth Shielding Durint CT Exams: A Literature Review. Radiology Management, 34(3).

[23] Hopper, K. D., Neuman, J. D., King, S. H., \& Kunselman, A. R. (2001). Radioprotection to the eye during CT scanning. American Journal of Neuroradiology, 22(6), 1194-1198. https://doi.org/10.1016/S00029394(01)01224-7

[24] Karami, V., Zabihzadeh, M., \& Shams, N. (2018). Bismuth radioprotective gonadal shields: Prevalence of use and effect on image quality during paediatric pelvic radiography. Hong Kong Journal of Radiology, 21(3), 178-183. https://doi.org/10.12809/hkjr1816863

[25] Karami, V., \& Zabihzadeh, M. (2015). Prevalence of radiosensitive organ shielding in patients undergoing computed tomography examinations: An observational service audit in Ahvaz, Iran. Asian Biomedicine, 9(6), 771-775. https://doi.org/10.5372/1905-7415.0906.449

[26] Winfeld, M., Strubel, N., Pinkney, L., Lala, S., Milla, S., Babb, J., et al. (2013). Relative distribution of pertinent findings on portable neonatal abdominal radiographs: can we shield the gonads? Pediatric Radiology, 43(10), 1295-1302. https://doi.org/10.1007/s00247-013-2700-7

[27] Kim, S., Frush, D. P., \& Yoshizumi, T. T. (2010). Bismuth shielding in CT: support for use in children. Pediatric Radiology, 40(11), 1739-43. https://doi.org/10.1007/s00247-010-1807-3 
[28] Karami, V., Zabihzadeh, M., \& Gholami, M. (2016). Gonad Shielding for Patients Undergoing Conventional Radiological Examinations: Is There Cause for Concern? Jentashapir Journal of Health Research, 7(2), e31170. https://doi.org/10.17795/jjhr-31170

[29] Moher, D., Shamseer, L., Clarke, M., Ghersi, D., Liberati, A., Petticrew, M., et al. (2015). Preferred reporting items for systematic review and meta-analysis protocols (PRISMA-P) 2015 statement. Systematic Reviews. 4(1), 1. https://doi.org/10.1186/2046-4053-4-1

[30] 34th Iranian Congress of Radiology. Retrieved October 2018, from https://en.symposia.ir/RADMED34

[31] 34th Iranian Congress of Radiology. Retrieved October 2018, from http://gsia.tums.ac.ir/en/dsem/ndt/351430/33rd-Iranian-Congress-of-Radiology--ICR

[32] Dowd, S. B., \& Tilson, E. R. (2004). Practical radiation protection and applied radiobiology: WB Saunders; 1999.

[33] Doolan, A., Brennan, P. C., Rainford, L. A., \& Healy, J. (2004). Gonad protection for the antero-posterior projection of the pelvis in diagnostic radiography in Dublin hospitals. Radiography, 10(1), 15-21. https://doi.org/10.1016/j.radi.2003.12.002

[34] Karami, V., Tahmasebi, M., Fatahi, \& Asl, J. (2013). The protection knowledge and performance of Radiographers in some hospitals of Ahvaz County. Jentashapir Journal of Health Research, 4(5), 405-12.

[35] Borhani, P., \& Mohammad, A. S. (2003). Evaluation of radiology personnel practice of Kerman university of medical sciences hospitals. 2003. https://doi.org/10.22038/ijmp.2015.6221

[36] Chaparian, A., Shamsi, F., \& Heydari, A. (2013). Assessment of awareness, attitude, and practice of radiographers about radiation protection in Yazd Province. Occupational Medicine Quarterly Journal, 5(1), $16-23$.

[37] Karami, V., Zabihzadeh, M., \& Sarikhani, S. (2016). Evaluation of the frequency and accuracy of gonad shield placement in patients undergoing pelvic radiography. Brazilian Journal of Radiation Sciences, 4(1), 1-8. https://doi.org/10.15392/bjrs.v4i1.189.

[38] Karami, V., Zabihzadeh, M., Shams, N., \& Sarikhani, S. (2016). Evaluation of the prevalence and utility of gonad shielding in pediatrics undergoing pelvic X-ray. International Journal of Pediatrics, 4(11), 3735-3740. https://doi.org/10.22038/ijp.2016.7589

[39] MacKay, M., Hancy, C., Crowe, A., D'Rozario, R., \& Ng, C. (2012). Attitudes of medical imaging technologists on use of gonad shielding in general radiography. Radiographer, 59(2), 35-9. https://doi.org/10.1002/j.2051-3909.2012.tb00172.x

[40] Karami, V., \& Zabihzadeh, M. (2012). Ovarian shielding during pelvis radiography: risk versus benefit. International Journal of Radiology and Radiation Therapy, 85, 442-447.

[41] Mehnati, P., \& Refahi, S. (2007). Assessment of radiation protection in the radiological centers: A pilot study in Ardebil. Proceedings of the 1 th congress of radiation protection in radiotherapy, diagnostic and interventionaal radiology; June 8-9 Tehran: shahid beheshti university of medical science, p. 1.

[42] Mirdoraghi, M., \& Fatahi, A. J. (2017). Evaluation of Radiation Protection Condition in Educational Hospital Radiological Centers of Ahwaz University of Medical Sciences. Paramedical Sciences and Military Health, 11(4), 1-8.

[43] Rostamzadeh, A., Farzizadeh, M., \& Fatehi, D. (2015). Evaluation of the level of protection in radiology departments of Kermanshah, Iran. Iranian Journal of Medical Physics, 12(3), 200-208. https://doi.org/10.22038/ijmp.2015.6221

[44] Bazrafshan, E., Mohamadi, J. L., Naroei, K., Parvaneh, H., \& Mohamadrigi, F. (2012). Survey of health and protection status of radiology centers covered by Zahedan University of Medical Sciences during 2010-2011.

[45] Rahimi, S., Salar, S., \& Asadi, A. (2007). Evaluation of technical, protective and technological operation of radiologists in hospitals of Mazandaran medical science universities. Journal of Mazandaran University of Medical Sciences, 17(61), 131-140.

[46] Tamjidi, A. (2001). Evaluation of applying protective principles against different rays in radiological centers in bushehr province, 2001.

[47] Praveen, B., Shubhasini, A., Bhanushree, R., Sumsum, P., \& Sushma, C. (2013). Radiation in dental practice: awareness, protection and recommendations. The Journal of Contemporary Dental Practice, 14(1), 143. 
https://doi.org/10.5005/jp-journals-10024-1289

[48] Evaz-Zadeh, N. (2001). Evaluation of the personal and environmental dosimetric status of diagnostic radiology departments in eastern Azarbayjan province: [MSc Thesis in medical physics]. Iran. Ahvaz Jundishapour Univercity of Medical Science 2001.

[49] Davoudiantalab, A. (2017). Survey of Compliance with Radiation Protection Standards in Diagnostic Imaging Centers of Khuzestan Province in 2015. Journal of Health Research in Community, 2(4), 1-10.

[50] Sheikhi, M., Khalilian, M., \& Raisi, N. (1998). Evaluation of radiation protection principles observance in dental x-ray centers in Isfahan county. Journal of Research In Medical Sciences, 3(4), 57-60.

[51] Goodarzi, P. D., Ebrahimi, M. S. (2004). Evaluation of x-ray protective measurements in intraoral radiography equipped centers in Yazd. Journal of Dental Medicine, 17(4), 61-7.

[52] Tavakkoli, A., Nikneshan, S., \& Varshousaz, M. (2004). Protection against X-Ray in dental clinics of Shahid Beheshti University of Medical Sciences in 1381.

[53] GhazikhanlouSani, K., Eskandarlou, A. (2009). Evaluation of radiation protection principles observance in Iranian dental schools. Journal of Dental Medicine, 22(3), 125-31.

[54] Halaji, A. (2006). Survey of dentist's knowledge \& behavior about radiation health in Tehran dental clinics: Thesis. Tehran: School of Dental, Tehran University of Medical Sciences, 2006.

[55] Badrian, H., Sheikhi, M., \& Abdinian, M. (2013). Knowledge, attitudes and performance of dental practitioners in Isfahan-Iran about biologic effects of ionizing radiation and protection against them in 2011. J. Mashad Dent. Sch., 37(1),19-26.

[56] Haghani, J., Raoof, M., Rad, M., Torabi-Parizi, M., \& Lotfi, S. (2017). Evaluation of X-ray protective shielding used in dental offices in Kerman, Iran, in 2014. Journal of Oral Health and Oral Epidemiology, 6(1), 27-32.

[57] Ahmadian, Y. A., Mortazavi, S., \& Rahmannia, G. (2018). Evaluation of the Compliance with the Principles of Radiation Protection in the Dental Offices in Mashhad, Iran. Journal of Mashhad Dental School, 42(1), 110.

[58] Shahab, S., Kavosi, A., Nazarinia, H., Mehralizadeh, S., Mohammadpour, M., \& Emami, M. (2012). Compliance of Iranian dentists with safety standards of oral radiology. Dentomaxillofacial Radiology, 41(2), 159-64. https://doi.org/10.1259/dmfr/29207955

[59] Javadzadeh, A., \& Alipour, H. (2011). Knowledge of general dentists about radiation protection in oral radiographic examinations in the city of Rasht-Iran in 2009. Recall, 3(2).

[60] Shahabi, N., Ghorbani-Shahna, F., Roknian, M., Goodarzi, S., Samavat, H., (Ed. 2004). Evaluation of radiation exposure to radiographers in teaching hospitals and private dental offices of Hamadan city in 2004. Proceedings of the 4th congress of environmental health of Iran 2004. Hamadan University of Medical Sciences.

[61] Karami, V., Zabihzadeh, M., Isavand-Faraji, A., Karampour, H. (2019). Radiological Protection in the Neonatal Intensive Care Units (NICU): A Retrospective and Observational Audit at Two Teaching Hospitals Supervised by Dezful University of Medical Sciences. Journal of Pediatric and Neonatal Individualized Medicine. 2019 In press. https://doi.org/10.7363/080126

[62] Tohidniya, M. R., Amiri, F., Khoshgard, K., \& Hormozi, M. Z. (2017). Evaluation of the Observance of Radiation Protection Principles in Intensive Care Units at Imam Reza Hospital of Kermanshah. Journal of Payavard Salamat, 10(6), 470-478.

[63] Mojiri, M., \& Moghimbeigi, A. (2011). Awareness and attitude of radiographers towards radiation protection.

[64] Bezanjani, N. J. (Ed. 2009). Study of personal protection performance for technologists and patients in diagnostic radiology departments of Kerman. Proceedings of the 12th congress of environmental health of Iran.

[65] Amirzadeh, F., Tabatabaie, S. (2006). Study of protection knowledge of technologists in Shiraz hospitals. Iran J. Nuclear Med., 13(24), 38-44.

[66] Rahimi, S. A., \& Salar, S. (2005). A study on the performance of recommended standards in the diagnostic radiology units of the hospitals affiliated to the Mazandaran University of Medical sciences. Journal of Mazandaran University of Medical Sciences, 15(49), 69-76. 
[67] Siavashpour, Z., Mehdizadeh, S., Farshadi, A., \& Baradaran-Ghahfarokhi, M. (2012). Radiation protection principles observance in mammography divisions in Shiraz. Iranian Red Crescent Medical Journal, 14(12), 840. https://doi.org/10.5812/ircmj.2004

\section{Copyrights}

Copyright for this article is retained by the author(s), with first publication rights granted to the journal.

This is an open-access article distributed under the terms and conditions of the Creative Commons Attribution license (http://creativecommons.org/licenses/by/4.0/). 